\title{
Teachers' Attitudes, Beliefs and Self-Efficacy about Multicultural Education: A Scale Development ${ }^{{ }^{*}}$
}

\author{
Soner Yildirim ${ }^{1}$, Erdoğan Tezci ${ }^{2, *}$ \\ ${ }^{1}$ Faculty of Education, Prizren "Ukshin Hoti” University, Kosovo \\ ${ }^{2}$ Necatibey Faculty of Education, Balıkesir University, Turkey
}

Copyright $(2016$ by authors, all rights reserved. Authors agree that this article remains permanently open access under the terms of the Creative Commons Attribution License 4.0 International License

\begin{abstract}
The purpose of this study is to develop a scale -acceptable to potential studies in the context of multicultural education- for determining teachers' attitudes, self-efficacy perceptions and beliefs regarding necessity of multicultural education. The items of the scale which were developed according to opinions of experts and literature were issued as five-level Likert scale based on teachers' subjective statements. The research was carried out in Kosovo which is the place of duty of native Turkish, Albanian and Bosnian speaking teachers and a culturally rich city. Therefore the scale was translated to Turkish, Bosnian and Albanian languages and applied to ten teachers to provide linguistic equivalence. After linguistic equivalence enabled, exploratory factor analysis have been conducted based on data that derived from 490 teachers in Kosovo. By results of analysis conducted based on varimax rotation, belief scale which has 9 items 2 factors, attitude scale which has 16 items and 3 factors and self-efficacy scale which has 13 items and 3 factors were determined. After factor structures revealed, Confirmatory Factor Analysis (CFA) was conducted. It was observed that fit indices obtained through CFA offer an acceptable value. The Cronbach's alpha reliability coefficients of all and sub dimensions of the scale were determined as high. On one hand it caused limitations that the study to be conducted in just one country on the other hand the country which is a culturally rich sample enhanced acceptability level of the scale. According to results of the study, the scales are available for determining teachers' attitude, belief and self-efficacy in the context of multicultural education.
\end{abstract}

Keywords Multicultural Education, Cultural Diversity, Attitude, Self-Efficacy, Beliefs, Scale Development, Teacher Education

\section{Introduction}

The culture, constituting the identity of a society and making it different from other societies, is the notion on which most studied and discussed, from different perspectives. It has become an issue of which has been spoken nationally and internationally more and more particularly in the context of the conception which has occurred along with the globalization fact. $[5,10,35,43]$. The nature of this notion and different approaches in meanings assigned to content of it can be regarded as cause of different definitions of it $[39,41,54,61,85]$.

In the dictionary of Turkish Language Association ([79]: 408-409) the notion of "culture" is defined as "moral and material values created in historical community development process and culture, all of the tools which indicates extent of control of man on his natural and social environment used in the process of transmission them to next generations and creating them". Wallerstein ([82]: 31) states that the notion of "culture" is used to define "common lifestyle" of societies who declares of intention to live together. As it is seen in definitions, for the notion of "culture", which reflects common values of a society, it can be said that it contains richness and diversity. Peterson [63] assumes some variables as belonging to the notion of culture such as race, nationality, ethnic origin, language and religion as well as social status, age such variables. As it is remarked in definitions, it can be said that the notion of culture includes ethnicity, diversity, pluralism and multiculturalism.

Cultural diversity within a general notion of culture brings together with the notion of multiculturalism. Communities in the same society develop different cultures according to their common background, hometown, economic field of occupations and socio-economic status ([26]: 27). This structure which consist of gathered different cultures is examined in the perspective of multiculturalism [16,62]. It is hard to make a common definition of multiculturalism as with the notion of culture despite the fact that multiculturalism occurred in its own terms along with the renaissance during historical process ([6,12,48]. Nevertheless, multiculturalism is discussed together with "diversity" [2]. Multiculturalism, inherently, may cause some problems such as lacking ability to live together, alienation and identity confusion for individuals from different cultures in terms of language, religion, race, social 
status, history, geography [50,78]. In this context, multicultural perspective is important for social peace and tolerance in a society of different cultural groups. Because multiculturalism as a life experience, may offer new opportunities to people [51].

Multicultural education has been come up to eliminate potential problems of multiculturalism and to make people take maximum advantage of multiculturalism $[4,8,16,27,60]$. Multicultural education is a reform movement which was designed to make some certain fundamental changes and arrangements in education system. Researches conducted in this regard show that all of the schools are to be reformed to implement multicultural education effectively $[9,40,59]$. Teachers' attitudes, beliefs and self-efficacy perceptions are conditions that has the potential of affecting reform efforts in multicultural education $[4,14,21,52,68]$. Because the person who will implement the program, create learning environment through choosing and varying appropriate methods and techniques and equipments to teach the cultural diversity and assess and evaluate learning is the teacher [11,38,58]

Intraclass behaviors of teachers on teaching practice of multicultural education is an important factor $[1,5,18]$ as well as presence of curriculum which are based upon multicultural education. Beliefs of teachers in necessity of multicultural education in class, their attitudes and opinions for multicultural education, their self-efficacy perceptions on what they can achieve through multicultural education are important in terms of achievement of multicultural education $[22,68,76]$. Being a responsive teacher to multiculturalism requires person to change his mentality and behaviours including his belief and attitude and in the same time to believe in himself $[4,5,29,68]$. Many studies $[18,52,55,69,80]$ suggest that there are positive changes on attitudes, beliefs and discourses about cultural diversity of teachers who received multicultural education training in the period of pre-service or in service education. According to Philips ([65]: 28) "cultural opinions on education and the effect of family and school are key factors of formation of teachers' beliefs."

Reactions and negative or positive acts of teachers to the students from different socioeconomic and culture, and attitudes of them to their own ethnic origin and diversities affect teaching period [27,31,70,71]. Hsu and Thomson [45] remarks that there will be considerable difficulties in providing equality of opportunity, forming culture specific learning experience and conducting teaching activities in an environment in which factor of attitude ignored. Positive attitude of teachers is effective as well as self-efficacy perceptions of them for teachers in overcoming difficulties which may occur in class environment as well as [13],[86]. Self-efficacy perceptions about the multicultural education of teachers will be able to allow an effective instructional design based on differences $[23,47,53]$. Teachers who have strict self-efficacy perception are able to organise proper learning for students who has different cultures, languages, religions and nationality through creating an appropriate class environment in terms of multicultural education by using various teaching methods and techniques and to evaluate whether terminal behaviours adopted by students $[19,72,75]$.

Beliefs, attitudes and self-efficacy perceptions of teachers are important in terms of implementing multicultural education programs effectively. But there is no comprehensive study in literature which is evaluating beliefs, attitudes and self-efficacy perceptions of teachers on the necessity of multicultural education. Therefore, developing an acceptable and reliable measurement tool which can be used in evaluating aforesaid variables was purposed in this study. By this way, progress of activities of program development to be conducted in terms of multicultural education and analyzing intraclass teaching practice from teacher's point of view will be contributed. Furthermore, the study will contribute to analyze current situation in terms of multicultural education.

\section{Method}

\subsection{Research group}

Two different samples were taken in the study. The first is to ensure the linguistic equivalent of 10 teachers. The second covers the reliability and factor analysis, working in various positions for 490 teachers in Kosovo. 294 teachers $(60 \%)$ women, $196(40 \%)$ were male. 80 Teachers $(16: 32 \%)$ Turkish, 230 (46.94\%) are Albanians and 180 (36.74\%) to Bosnian.

\subsection{Measurement Tools}

Multicultural classroom teachers' beliefs about the training requirements, a scale for determining multicultural attitude and self-efficacy perception of the teaching-learning process. Based on the subjective scale as teachers with expression $5=$ Strongly Agree, $4=$ Agree, $3=$ Neutral, $2=$ Disagree, $1=$ Strongly Disagree, and is organized as five-point Likert being.

\subsection{Creation of Items Pool}

Literature was examined primarily in the development of scale $[4,5,12,13,21,22,26,30,32,36-38]$. Following the review of the literature item pool was created. 13 items for belief scale; 19 items for the attitude scale; 18 items are intended for self-efficacy scale. After items pool is created and converted into five-point Likert scale form. 5-point Likert scale converted form face validity and on multicultural education in terms of content validity has been submitted to the five experts. Experts have to go to any improvement on the scale, and it is determined that in view of the journal in terms of coverage. 


\subsection{Implementation of the Scale and Analysis Process}

We have to be applied to research from three different native language teachers in Kosovo has been administered primarily face 10 teachers to ensure linguistic equivalence. 7 of those teachers (4 Turkish and Albanian, Turkish-Bosnian 3 ) speaking two different languages, two different texts that can be read and understand the language and the ability to write in two different languages; three consists of the knowledge of all three languages. 6 of these teachers have a Turkish mother tongue, 2 Bosnian and 2 with Albanian teachers are native speakers. Involving a questionnaire containing demographic information (gender, seniority and branches) to determine the reliability and construct validity of the analysis was done with the data of 490 teachers. First to determine the factorial structure of the Exploratory Factor Analysis (EFA) later to test the accuracy and fitness of the model structure of these factors have made Confirmatory Factor Analysis (CFA). Cronbach's alpha values for reliability were investigated.

\section{Findings}

\subsection{Face Validity and Linguistic Equivalence}

After the scales were created, asked for help of experts to examine the scales in terms of concept and face validity. For this purpose, help of 5 academic members who study in the area of multicultural education was received. Experts corrected 1 item in attitude scale and 2 items in self-efficacy scale. After compositions and items of the scales were finalized, items which were created in Turkish were translated into Albanian and Bosnian.

Scale forms were applied to teachers who speak Turkish-Bosnian, Turkish-Albanian, and Turkish-Albanian-Bosnian language every other week in person to determine whether these scales were compatible with each other in terms of linguistics. Items were relocated in each form. After the implementation process, a high correlation level between forms in Turkish, Bosnian and Albanian $(\mathrm{r}=.85)$ was determined. It was controlled that whether statements written in different languages have same meaning by asking teachers in the process of pre-application that whether statements were same in each form and what they understand from each language form. Linguistic equivalence of the audit work on the scale that forms in different languages did not go to any changes.

\subsection{Determination of convenience to be analyzed and reliability of measurements}

These were examined that whether measurements obtained through implementing the scale to 490 teachers are sufficient and their compatibility to be analyzed. First Kaiser Meyer Olkin the Measure of Sampling adequacy (KMO) and Bartlett's test of value Sphericity values were examined. $\mathrm{KMO}$ value is between 1 and 0 , and this indicates that as 1 is approached above .60 measurements provide acceptable and reliable factors for factor analysis [24,49]. It was found that $\mathrm{KMO}$ value of the belief scale was .812 ; attitudes scale was .784 and the self-efficacy scale was .860 . Bartlett's test of Sphericity value compares the identity matrix with the observed correlation matrix. In other words, it is used to analyze equality of a certain number sample variances. Being significant of this value supports factorability of item-related correlation matrix. [49]. Bartlett's test of Sphericity values of beliefs, attitudes and self-efficacy scales were respectively found high as Approx Chi-Square $=4114.270(\mathrm{p}<.01), 1034.465(\mathrm{p}<.05), 1722(\mathrm{p}<.05)$.

Reliability which is one of the technical virtues of measurement tool is a significant indicator of that whether this tool measures features always in the same way ([77]: 57). Cronbach Alpha reliability coefficient is examined in terms of reliability, which is a precondition for acceptability, in cases which scales like Likert implemented once to a group. [74]. In this study, Cronbach's alpha reliability coefficients regarding almost all of the scales was determined as .737 for belief scale, .654 for attitude scale and .786 for self-efficacy scale. Both KMO and Bartlett's test of Sphericity values and reliability analysis results indicate that measurements are fit to conduct factor analysis.

\subsection{Exploratory Factor Analysis}

With the aim of revealing the factor structures of scales EFA was conducted principally. EFA is one of the examination ways that is used to inquire about nature of the measured factors instead testing a certain hypothesis when number of the measured factors is unknown $[49,73,74]$. To this end, the Principal Component Analysis was conducted. Moreover, obtained data was also processed to varimax rotation to provide "independence, openness and significance in explication". In studies conducted in social sciences items with the .40 or above factor loading were selected [81].

Four of the 13 items created for belief scale were excluded; two of them were complexity variables and two of them had factor loading under .40 (.238 and .316). 3 of the 19 items created for attitude scale and 5 of the 18 items created for self-efficacy scale were excluded as that of 19 had factor loading under .40 and that of $18 ; 3$ of them were complexity variables and 2 of them had factor loading under .40 $(.318, .211, .378)$. According to analytic results which was conducted, after items which were complexity variables or had low factor loading excluded in each scale, by processing varimax rotation again; two subdimensions were determined in belief scale; one of them was "belief about individual right" composed of 4 items and the other was "general right for man" composed of 4 items. It was determined for attitude scale that it was composed of 3 subdimensions as "Negative judgments about cultural diversity" with 7 items, "Adoption of cultural diversity" with 5 items and "Attach importance to cultural diversity" with 3 items. And it was determined for self-efficacy scale that it was composed of 3 subdimensions as "Designing activity about cultural diversity" with 5 items, "Managing diversity" with 5 items and "Understanding diversity" with 3 items. Table 1 also shows the results of principal component analysis and Cronbach's alpha values as indicators of internal consistency of the participants' responses (reliability analysis). 
Table 1. Results of factor and reliability analysis.

\begin{tabular}{|c|c|c|c|c|}
\hline Scale & Sub dimension & $\begin{array}{l}\text { Item } \\
\text { Number } \\
\end{array}$ & $\%$ of Variance & $\begin{array}{l}\text { Cronbach' } \\
\text { Alpha }\end{array}$ \\
\hline \multirow[t]{2}{*}{ Belief } & Belief about individual right & 4 & $23.362 \%$ & .67 \\
\hline & General right for man & 5 & $22.217 \%$ & .63 \\
\hline \multicolumn{2}{|c|}{ Belief Scale General } & 9 & $45.583 \%$ & .75 \\
\hline \multirow[t]{3}{*}{ Attitude } & Negative judgments about cultural diversity & 7 & $20.871 \%$ & .78 \\
\hline & Adoption of cultural diversity & 5 & $15.024 \%$ & .70 \\
\hline & Attach importance to cultural diversity & 4 & $14.935 \%$ & .70 \\
\hline \multicolumn{2}{|c|}{ Attitude Scale General } & 16 & $50.830 \%$ & .73 \\
\hline \multirow[t]{3}{*}{ Self-Efficacy } & Designing activity about cultural diversity & 5 & $19.507 \%$ & .76 \\
\hline & Managing Diversity & 5 & $17.181 \%$ & .69 \\
\hline & Understanding diversity & 3 & $16.695 \%$ & .73 \\
\hline \multicolumn{2}{|c|}{ Self-efficacy Scale General } & 13 & $53.383 \%$ & .88 \\
\hline
\end{tabular}

According to factor analysis results, items with the lowest factor loadings of belief, attitude and self-efficacy scales are respectively $(.461, .512, .475)$ : "To get to know different cultures, I believe it helps to see the different options" with", "would avoid sharing their cultural identity with my students in my classroom", "educational needs of students with different cultural values / can meet their needs". The item with the highest factor loading (.818) which belongs to self-efficacy scale is "data and methods based on different learning styles can apply my experience". Items and factor loadings of scales are figured in Appendix 1. It was determined for reliability coefficient to be higher after items excluded from scales. Reliability coefficients of belief, attitude and self-efficacy scales are respectively determined as $.75, .73$ and .88 . The correlation between dimensions of belief scale are moderate and positive $(\mathrm{r}=.65, \mathrm{p}<.05)$. There is moderate and negative correlation between these dimensions of attitude scale: "Negative judgment" and "Attach importance to cultural diversity" ( $r=-.43, \mathrm{p}<.05)$; "Negative judgment" and "Adoption of cultural diversity" $(\mathrm{r}=-55, \mathrm{p}<.05)$. And there is moderate and positive correlation between "Attach importance to cultural diversity" and "Adoption of cultural diversity" $(\mathrm{r}=.62)$. Positive and significant relation was determined between these items of self-efficacy scale: "Designing activity about cultural diversity" and "Managing Diversity" ( $\mathrm{r}=.53, \mathrm{p}<.05)$; "Designing activity about cultural diversity" and "Understanding diversity" ( $\mathrm{r}=.47, \mathrm{p}<.05)$; "Understanding diversity" and "Managing Diversity" ( $\mathrm{r}=.51, \mathrm{p}<.05)$.

\subsection{Confirmatory Factor Analysis}

Confirmatory Factor Analysis (CFA), based on the variable observed through a predetermined pattern is a process for creating latent variables $[15,17,25]$ It was purposed that conduct CFA to examine the model figured in EFA and to test acceptability of it. It is used to examine that whether these factors which are determined by EFA are adequately related; which variables are correlate with which factors; whether these factors are independent of each other; whether these factors are adequate to explain the model[ $[17,73]$. In this study CFA was conducted to examine accuracy of the structure determined by EFA and to determine acceptability and conformability of the model, in other words to examine significance of relation between variables determined and observed by theoretical structure. Belief scale of the Chi-square analysis is $\chi^{2} / \mathrm{sd}=2.336$ $\left(\chi^{2}=60.74, \mathrm{df}=26\right)$; Attitude scale of the Chi-square analysis is $\chi^{2} / \mathrm{sd}=3.295\left(\chi^{2}=326.22, \mathrm{df}=99\right)$ and Self Efficacy scale of the Chi-square analysis is $\chi^{2} / \mathrm{sd}=1.777\left(\chi^{2}=108.44, \mathrm{df}=61\right)$. However, other fit indices were examined because of the fact that this indice was influenced by sample size. It was determined according to conducted examination that fit indices of belief and self-efficacy scales are low. Therefore modifications made in attitude scale for 3 error covariance and in self-efficacy scale for 2 error covariance. As a result of modification accuracy observed in fit indices and the model has become simpler. Results of the analysis are figured in Table 2.

No modifications were made in belief scale. Resulting indices fits with two factor model $(\mathrm{GFI}=0.97$; AGFI $=.95$, $\mathrm{CFI}=.98 ; \mathrm{NFI}=0.96, \mathrm{t}=0.97 \mathrm{NNF})$. After the inclusion of three error covariances (namely between the items 3 and 6;9 and 11, 13 and 16) a fit Attitude Scale was obtained $(\mathrm{GFI}=0.92 ; \mathrm{AGFI}=.90 ; \mathrm{CFI}=.92 ; \mathrm{NFI}=0.90, \mathrm{NNFI}=0.91)$. Similarly, after the inclusion of two error covariances (namely between the items 6 and 7,9 and 10) a fit self-efficacy scale was obtained $(\mathrm{GFI}=0.97$; AGFI $=.95$, $\mathrm{CFI}=.99 ; \mathrm{NFI}=0.97, \mathrm{NNF}$ is $=0.98)$. These were determined that standardised correlations between implicit and observed variables of all scales were significant and all standardised values drawn in path diagram were below 1 [73]. 
Table 2. Goodness of fit indices for CFA for measurement models

\begin{tabular}{lccccc}
\hline & Belief Scale & Attitude Scale & & Self-Efficacy Scale \\
\hline \multicolumn{1}{c}{ Index } & Value & $\begin{array}{c}\text { 3 Factor } \\
\text { Model }\end{array}$ & $\begin{array}{c}\text { 3 Factor with } \\
\text { 3 error covariances }\end{array}$ & 3 Factor Model & $\begin{array}{c}\text { 3 Factor with 2 } \\
\text { error covariances }\end{array}$ \\
\hline$X^{2}$ & 60.74 & 326.22 & 318.47 & 108.39 & 105.24 \\
df & 26 & 99 & 96 & 61 & 60 \\
$\mathrm{p}$ & $<0.001$ & $<0.001$ & $<0.001$ & $<0.001$ & $<0.001$ \\
GFI & 0.97 & 0.92 & 0.92 & 0.94 & 0.97 \\
AGFI & 0.95 & 0.88 & 0.90 & 0.91 & 0.95 \\
CFI & 0.98 & 0.90 & 0.92 & 0.01 & 0.99 \\
RMSEA & 0.05 & 0.076 & 0.90 & 0.91 & 0.039 \\
NFI & 0.96 & 0.90 & 0.91 & 0.93 & 0.97 \\
NNFI & 0.97 & 0.90 & 0.010 & 0.039 & 0.98 \\
RMR & .019 & 0.022 & 515.746 & 495.136 & 0.021 \\
AIC & 501.136 & 678.134 & & & 454.324 \\
\hline
\end{tabular}

\section{Results, Conclusions and Recommendations}

In this study, developing an acceptable and reliable scale to determine belief, attitude and self-efficacy perceptions of teachers about multicultural education was purposed. Examining acceptability and reliability of the scales was purposed. There are scales which developed in terms of different contexts in literature $[51,57,67,72]$ Berry \& Kalin [19], Constantine [28] have developed a scale regarding attitude and self-efficacy. However, these studies are related with multiculturalism and diversity more than multicultural education in the classroom. Studies to develop scales about which attitude to multicultural education and belief in necessity of multicultural education and self-efficacy perceptions are limited (E.g.[42,66]). Contributing to multicultural education studies by developing a comprehensive scale based upon perceptions of teachers about multicultural education was purposed in this study.

Questionnaire data were collected during development process of the scale from teachers working in Kosovo. Teachers who participated in this study were the ones teaching in their native languages; Turkish, Albanian and Bosnian. Therefore after the scale which was developed in Turkish translated to Albanian and Bosnian, with the purpose of providing linguistic equivalence, forms of the scale in each language was applied to 10 teachers who could speak at least two of these languages every other week and high correlation was determined between measurements. Moreover, linguistic equivalence ensured by that either forms were given and the item in each scale were made read and then teachers were asked to state the same item in the form in other language. After linguistic equivalence ensured, scales were applied to 490 teachers. They were first analyzed by Exploratory Factor Analysis. In results of the analysis conducted, it was observed that scales of belief, attitude and self-efficacy were respectively composed of 2,3 and 3 factors. Higher eigenvalue and variance ratio were obtained through excluding 4 items in belief scale, 3 items in attitude scale and 5 items in self-efficacy scale. In addition, the reliability of the scales was higher. Cronbach Alpha reliability coefficients of the almost whole of the belief, attitude and self-efficacy scales are respectively $0.73,0.88$ and 0.75 . Except the subdimension of the attitude scale which was "Negative judgment about cultural diversity", moderate and positive correlation between all of the scales and their subdimensions was determined. Thus, significant and negative relation was determined in the subdimension of "Negative judgment about cultural diversity".

Implicit factors found in the structure of the scale and dependent effects between these factors were analyzed through Confirmatory Factor Analysis. Results indicate that obtained fit indices had acceptable and high levels. In addition, each of the implicit variables and their observed standardised factor loadings were determined as high. Each factor was found to be statistically significant. It was determined that values obtained through EFA provided similar results with those obtained through CFA. Relation between the factors of the scales of belief, attitude, and perception was found significant $(p<.01)$. Values standardised between analyzed implicit variables were found to be below 1[73]. It was seen that values obtained through CFA and EFA of collected data and Cronbach's Alpha reliability coefficients of measurements obtained by the scale both occurred in an acceptable range. Furthermore, also the results of the discrimination analysis regarding almost whole of the items, subdimensions and scales shows that there were significant differences between scores of divisions and subdivisions.

Item-total correlations of measurements obtained from the scale were determined to be high. It is essential that item-total correlations and factor loadings of measurements obtained through scale adaptation studies to be acceptable with regard to indicating the scale is acceptable to different studies. These results suggest the findings of many studies indicating that high levels of belief, attitude and self-efficacy about multicultural education in literature positively affect studies on this field $[33,83,84,86,87]$. The study of scale on beliefs of preservice teachers about multicultural education conducted by Siwatu (2007) was modified like studies on other fields (technology, special education). This work is discussed in the context of multicultural teaching practices of teachers with linguistic differences. In this regard the results of the study suggests studies based upon linguistic 
differences about multicultural teacher education in literature $[34,75]$.

Hachfeld et al. [44], have determined relation between beliefs and attitudes in their scale developing study on multicultural beliefs. Kathleen [46], Pettus and Allain [64] have determined relation between beliefs and attitudes in their studies on discrepancies. Researchers determined that teachers who have strict beliefs and attitudes on multiculturalism and diversity behave more positively in classes which have ethnic, religious, socio-economic etc. diversity. Some studies conducted in this field $[1,10,64]$ suggest that teachers who have strict beliefs and positive attitudes about multicultural education find themselves competent on multicultural education in classes and teaches in this way.

Summarily, results obtained by the research shows that scales are reliable and have moderate correlation between them. Factor structures determined by EFA and fit indices determined by CFA of all scales provide results at good level.
The results show that the scales are acceptable to determine beliefs, attitudes and self-efficacy perceptions of teachers about multicultural education. However, it would be helpful to examine these scales also in different cultures. Thus, it will help scales to be applied at international level. It would be helpful that to regulate pre-service and in-service training programmes of teachers by examining approaches of teachers to multicultural education in multicultural classes. It would also be helpful that to examine relation of the scales with multicultural education practices. One of the limitedness of this study is that analyzes conducted based upon the data collected from teachers who live in similar cultural environment. Therefore, criterion validity of the scale could not be examined. It will be good for future studies that to conduct analyze based upon data collected from groups which have no cultural diversities like linguistic or religious. It will be helpful that to research how this situation affects performances of teachers and to compare collected data with results of the scales.

\section{Appendix: Scale Items and Factor Loadings}

\section{Distribution of the Items of Belief Scale and Factor Loadings}

\begin{tabular}{|c|c|c|}
\hline Size & Material & $\begin{array}{l}\text { Factor } \\
\text { loading }\end{array}$ \\
\hline \multirow{4}{*}{ 㺼 } & I believe that there is a need to protect the dignity of each culture. & .673 \\
\hline & I believe that individuals should be free to choose their religion. & .704 \\
\hline & I believe that each culture should be evaluated according to their own values and norms. & .594 \\
\hline & I believe that each culture should be supported in order to improve himself. & .737 \\
\hline \multirow{5}{*}{ 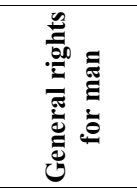 } & I believe that the recognition of different cultures helps to see the different options. & .461 \\
\hline & I believe that the value of the diversity of beliefs and way of life is an inseparable part of being human. & .485 \\
\hline & I understand cultural diversity, but I believe that as we are human we need to focus on the similarities. & .638 \\
\hline & I believe, there should be a climate that supports multiculturalism in schools. & .651 \\
\hline & I believe that in learning activities students with different cultural backgrounds should be taken into account. & .746 \\
\hline
\end{tabular}

According to Factor and Load Factor Distribution of Items Involved in Attitude Scale

\begin{tabular}{|c|c|c|}
\hline Size & Material & $\begin{array}{l}\text { Factor } \\
\text { loading }\end{array}$ \\
\hline \multirow{6}{*}{ 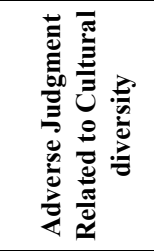 } & I find strange, peculiar behavior values and attitudes toward different cultures * & .743 \\
\hline & I think being in contact with students belonging to different cultures cause discomfort*. & .808 \\
\hline & I prefer to teach in a classroom of students with similar cultural backgrounds*. & .634 \\
\hline & I avoid sharing my cultural identity with my students in the classroom.* & .512 \\
\hline & I disagree on giving importance to cultural diversity.* & .545 \\
\hline & Teachers do not need to have information about multicultural education * & .625 \\
\hline \multirow{5}{*}{ 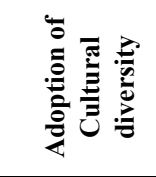 } & I pay attention to learn cultural dynamics of the group that I am in & .644 \\
\hline & I care about students' descriptions of their own cultural values easily & .749 \\
\hline & I think different gender, faith, ethnicity that are the value of judgments is the richness of that language in class & .765 \\
\hline & I enjoy teaching in multicultural class & .664 \\
\hline & I care about the students cultural features in classroom activities & .583 \\
\hline \multirow{3}{*}{ 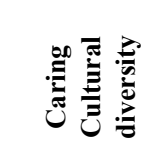 } & In the debates of classroom I would prevent the emergence of cultural diversity* & .718 \\
\hline & I questioned my own cultural history & .770 \\
\hline & I don't think that students are superior or poor from each other in cultural aspects & .652 \\
\hline
\end{tabular}

*Reverse Coded Items 
According to Factor and Load Factor Distribution of Items Involved in Self-Efficacy Scale

\begin{tabular}{|c|c|c|}
\hline Size & Material & $\begin{array}{l}\text { Factor } \\
\text { loading }\end{array}$ \\
\hline \multirow{5}{*}{ 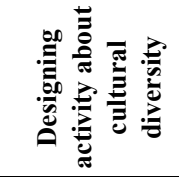 } & Based on my knowledge and experiences I can choose different learning styles methods. & .786 \\
\hline & Based on my knowledge and experiences I can apply different learning styles methods & .818 \\
\hline & I can understand the problems caused by the cultural experiences, values and the way of life & .638 \\
\hline & I can solve the problems caused by the cultural experiences, values and the way of life & .520 \\
\hline & I can help with students from different cultures to adapt in a new cultural environment (grade-school) & .541 \\
\hline \multirow{5}{*}{ 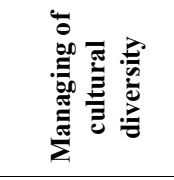 } & I can design the material, taking into account cultural diversity & .635 \\
\hline & I can communicate with students from different cultures effectively & .674 \\
\hline & I can show sensitivity to different cultures & .634 \\
\hline & I can conduct a study dealing with cultural diversity in my school or in my class. & .671 \\
\hline & I can meet educational needs of students with different cultural values. & .475 \\
\hline \multirow{3}{*}{ 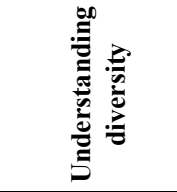 } & I am aware of the impact of culture on the attitude, beliefs and behaviors & .782 \\
\hline & I can understand the impact of culture on students' attitude, beliefs and behavior & .778 \\
\hline & I can designing teaching activities, taking into account the cultural characteristics of students & .615 \\
\hline
\end{tabular}

\section{Note}

*The abstract of this paper was presented at 2nd International Conference on Lifelong Learning and Leadership for All (ICLEL-16), in Liepaja on July, 21-23, 2016.

\section{REFERENCES}

[1] Acquah, E. O., \& Commins, N. L. (2013). Pre-service teachers' beliefs and knowledge about multiculturalism. European Journal of Teacher Education, 36(4), 445-463.

[2] APA (2002). Guidelines on multicultural education, training, research, practice, and organizational change for psychologists. Retrieved 08 July 2015, from: http://www.apa.org/pi/oema/resources/policy/multicultural-g uideline.pdf

[3] Aşkar, P. \& Umay, A. (2002). İlköğretim Matematik bölümü öğrencilerinin bilgisayarla ilgili öz-yeterlik algısı. Hacettepe Üniversitesi Eğitim Fakültesi Dergisi, 21(21), 1-8.

[4] Aydin, H. (2012). Multicultural education curriculum development in Turkey. Mediterranean Journal of Social Science, 3(3), 277-287.

[5] Aydın, H. (2013). Dünyada ve Türkiye'de Çokkültürlü Eğitim Tartışmaları ve Uygulamaları. Ankara: Nobel Yayıncilik.

[6] Aytaç, K. (2009). Avrupa Eğitim Tarihi. Ankara: Doğu-Batı Yay.

[7] Babacan, D. (1999). Öğretmenlerin Öğrencilerine Yönelik Tutumları ve Güdüleri. Yayınlanmamış Yüksek Lisans Tezi, Dokuz Eylül Üniversitesi, İzmir.

[8] Banks, J. A. (2013). Çokkültürlü Eğitime Giriş. (Çev. Aydın, H.). Ankara: Anı Yayınları.

[9] Banks, J. A. (2011). Educating citizens in diverse societies. Intercultural Education, 22(4), 243-251.

[10] Banks, J. A. (2010). Multicultural education: Characteristics and goals. (Eds: J. A. Banks \& J. A. M Banks), Multicultural
Education: Issues and Perspectives, (pp. 1-32). Rosewood Drive, Denver: Willey.

[11] Banks, J. A. (2007). Diversity and Citizenship Education: Global Perspectives. Jossey-Bass, An Imprint of Wiley. 10475 Crosspoint Blvd, Indianapolis, IN 46256.

[12] Banks, J. A. (2001). Citizenship education and diversity: Implications for teacher education. Journal of Teacher Education, 52(1), 5-16.

[13] Bandura, A. (1993). Perceived self-efficacy in cognitive development and functioning. Educational Psychologist, 28(2), 117-148.

[14] Barry, N. H., \& Lechner, J. V. (1995). Preservice teachers' attitudes about and awareness of multicultural teaching and learning. Teaching and Teacher Education, 11(2), 149-161.

[15] Bayram, N. (2010). Yapısal Eşitlik Modellemesine Giriş. Bursa: Ekin Kitabevi.

[16] Bennett, C. I. (1999). Comprehensive Multicultural Education: Theory and Practice. Boston: Allyn and Bacon.

[17] Bentler, P. M., \& Bonett, D. G. (1980). Significance tests and goodness of fit in the analysis of covariance structures. Psychological Bulletin, 88(3), 588-606.

[18] Bernstein, E., \& Lysniak, U. (2015). Teachers' beliefs and implementation of competitive activities for multicultural students. Urban Education, DOI:

$10.1177 / 0042085915602535$.

[19] Berry, J. W., \& Kalin, R. (1995). Multicultural and ethnic attitudes in Canada: An overview of the 1991 National Survey. Canadian Journal of Behavioural Science/Revue Canadienne Des Sciences Du Comportement, 27(3), 301.

[20] Bjorklund, D. F. (2000). Children's Thinking: Developmental Function and Individual Differences. Belmont, CA, US: Wadsworth/Thomson Learning.

[21] Brown, M. N. (2007). Educating all students: Creating culturally responsive teachers, classrooms, and schools. Intervention in School and Clinique, 43(1), 57-62.

[22] Brown, S. C. \& Kysilka, M. (2002). Applying Multicultural and Global Concepts in the Classroom and Beyond. Boston, MA: Allyn ve Bacon. 
[23] Bulut, C. \& Başbay. A. (2015). Determination of teachers' multicultural competence perceptions. K. Ü. Kastamonu Eğitim Dergisi, 23(3), 957-978.

[24] Büyüköztürk, Ş. (2003). Sosyal Bilimler İçin Veri Analizi El Kitabı: Ankara: Pegem Yay.

[25] Büyükzötürk, Ş., Şekercioğlu, G. \& Çokluk, O. (2014). Sosyal Bilimler İçin Çok Değişkenli İstatistik: SPSS ve Lisrel Uygulamaları. Ankara: Pegem Akademi Yay.

[26] Cırık, İ. (2008). Çokkültürlü eğitim ve yansımaları. Hacettepe Üniversitesi Eğitim Fakültesi Dergisi, 34, 27-40.

[27] Çiftçi, Y. \& Aydın, H. (2014). Türkiye'de çokkültürlü eğitimin gerekliliği üzerine bir çalışma. SDÜ Fen Edebiyat Fakültesi, Sosyal Bilimler Dergisi, 33, 197-218.

[28] Constantine, M. G. (2002). Racism attitudes, White racial identity attitudes, and multicultural counseling competence in school counselor trainees. Counselor Education and Supervision, 41(3), 162.-174.

[29] Darling-Hammond, L. (2016). Research on teaching and teacher education and its influences on policy and practice. Educational Researcher, 45(2), 83-91.

[30] Fergeson, L. (2008). Çokkültürlülüğe Giriş. (Ed: Yiannis Laouris), Nicoisa, Cyprus: Future Worlds Center. Retrieved 5 October 2015, from:

http://docplayer.biz.tr/3950917-Cok-kulturluluge-giris.html

[31] Fındıkçı, İ. (1991). Öğretmenlerin Disiplin Konusundaki Tutumları. Eğitimde Nitelik Geliştirme, Eğitimde Arayışlar 1. Sempozyumu Bildiri Metinleri. İstanbul: Kültür Yayınları.

[32] Furman, G. C. \& Shields, C. M. (2005). How can educational leaders promote and support social justice and democratic community in schools. (Eds: W. A. Firestone \& C. Riehl) A new agenda for research in educational leadership, (pp. 119-137). New York: Teacher College Press.

[33] Ford, D. Y., \& Harris, J. J. (1996). Perceptions and attitudes of Black students toward school, achievement, and other educational variables. Child development, 67(3), 1141-1152.

[34] Gallego, M. A. (2001). Is experience the best teacher? The potential of coupling classroom experience and community based field experiences. Journal of Teacher Education, 52(4), 312-325.

[35] Galley, C. C. (2001). Cultural policy, cultural heritage and regional development. Unpublished Master Thesis. The State University of New Jersey, New Jersey.

[36] Gay, G. (2002). Preparing for culturally responsive teaching. Journal of Teacher Education, 53, 106-116.

[37] Gay, G. (1995). Bridging multicultural theory and practice. Multicultural Education, 3(1), 4-9.

[38] Gay, G. (1994). A Synthesis of Scholarship in Multicultural Education. Urban Monograph Series. Office of Educational Research and Improvement. North Central Regional Educational Lab., Oak Brook, IL. ERIC, ED 378287.

[39] Geertz, C. (1995). After the Fact: Four Decades, Two Countries, One Anthropologist. Cambridge, MA: Harvard University Press.

[40] Gillborn, D. (2008). Racism and Education: Coincidence or Conspiracy? New York: Routledge.
[41] Gray, C. (2004). Joining-up or tagging on? The arts, cultural planning and the view from the below. Public Policy and Administration, 19(2), 38-49.

[42] Guyton, E. M., \& Wesche, M. V. (2005). The multicultural efficacy scale: Development, item selection, and reliability. Multicultural Perspectives, 7(4), 21-29.

[43] Güvenç, B. (1994). İnsan ve Kültür (6. Bask1). İstanbul: Remzi Kitabevi.

[44] Hachfeld, A., Hahn, A., Schroeder, S., Anders, Y., Stanat, P., \& Kunter, M. (2011). Assessing teachers' multicultural and egalitarian beliefs: The teacher cultural beliefs scale. Teaching and Teacher Education, 27(6), 986-996.

[45] Hsu, S. H. T. \& Thomson, R. C. (2010). Multiculturalism in secondary school physical education textbooks. Journal of Teaching in Physical Education, 29, 199-220.

[46] Kathleen M. B. (2004). Assessing preservice leaders' beliefs, attitudes, and values regarding issues of diversity, social justice, and equity: A review of existing measures. Equity \& Excellence in Education, 37(4), 332-342, DOI: http://dx.doi.org/10.1080/10665680490518948.

[47] Kaya, A. (2013). Multiculturalism: The culturalisation of what is social and political. Perceptions, 18(3), 63-91.

[48] Keskin, Y. \& Yaman, E. (2014). İlköğretim Sosyal Bilgiler programı ve ders kitaplarında yeni bir paradigma: Çokkültürlü eğitim. Turkish Studies - International Periodical for the Languages, Literature and History of Turkish or Turkic, 9(2), 933-960.

[49] Kline, P. (1994). An Easy Guide to Factor Analysis. New York, NY: Routledge.

[50] Kymlicka, W. (2004). Marketing Canadian pluralism in the international arena. International Journal, 59(4), 829-52.

[51] Marangoz, G., Aydın, H. \& Adıgüzel, T. (2015). Öğretmenlerin çokkültürlü eğitime karşı algısı. International Periodical for the Languages, Literature and History of Turkish or Turkic, 10(7), 709-720.

[52] Martin, R. J., \& Dagostino-Kalniz, V. (2015). Living Outside Their Heads: Assessing the Efficacy of a Multicultural Course on the Attitudes of Graduate Students in Teacher Education. Journal of Cultural Diversity, 22(2), 43-49.

[53] Määttä, S. (2008). Teachers' perceptions of multicultural education and their competence to teach children from different cultural backgrounds. Unpublished Pro Gradu -Thesis. University of Jyväskylä, Israel.

[54] Mejuyev, V. (1987). Kültür ve Tarih. (Çev. S. H. Yokova). Ankara: Başak Yayınları.

[55] Middleton, V. A. (2001). Increasing preservice teachers' diversity beliefs and commitment. The Urban Review, 33(4), 343-361.

[56] Morgil, İ., Seçken, N. \& Yücel A. S. (2004). Kimya öğretmen adaylarının öz-yeterlik inançlarının bazı değişkenler açısından incelenmesi. Balıkesir Üniversitesi Fen Bilimleri Enstitüsü Dergisi, 6(1), 62- 72.

[57] Munroe, A., \& Pearson, C. (2006). The Munroe multicultural attitude scale questionnaire: A new instrument for multicultural studies. Educational and Psychological Measurement, 66(5), 819-834. 
[58] Neuharth-Pritchett, S., Reiff, J. C. \& Pearson, C. A. (2001). Through the eyes of preservice teachers: Implications for the multicultural. Journal of Research in Childhood Education, 15(2), 256-269.

[59] Nieto, S. (2012). United States, multicultural education (Ed: J. A. Banks). Encyclopedia of Diversity in Education, 4, 2248-2253. Thousand Oaks, CA: Sage Pub. DOI: http://dx.doi.org/10.4135/9781452218533.n709

[60] Nieto, S. (1994). Moving beyond tolerance in multicultural education. Multicultural Education, 1(4), 35-38.

[61] Oğuz, E. S. (2011). Toplum bilimlerinde kültür kavramı. Edebiyat Fakültesi Dergisi, 28(2), 123-139.

[62] Pang, V. O. (2001). Multicultural education: A caring-centered, reflective approach. PO Box Columbus: McGraw-Hill,

[63] Peterson, P. B. (1991). Multiculturalism as a generic approach to counseling. Journal of Counseling and Development, 70, 6-12.

[64] Pettus, A., \& Allain, V. A. (1999). Using a questionnaire to assess prospective teachers' attitudes toward multicultural education issues. Education, 119(4), 651-657.

[65] Phillips, M. S. (2009). Beginning Teacher Beliefs and Wise Practices: A Case Study of A High School Social Studies Teacher. Unpublished Dissertation, University of Florida, Florida, USA.

[66] Pohan, C. A. (1996). Preservice teachers' beliefs about diversity: Uncovering factors leading to multicultural responsiveness. Equity and excellence in education, 29(3), 62-69.

[67] Ponterotito, J. G., Baluch, S., Greig, T., \& Rivera, L. (1998). Development and initial score validation of the teacher multicultural altitude survey. Educational and Psychological Measurement, 58(6), 1002-1016.

[68] Polat, S. (2009). Öğretmen adaylarının çokkültürlü eğitime yönelik kișilik özellikleri. International Online Journal of Educational Sciences, 1(1), 154-164.

[69] Sharma, U. \& Nuttal, A. (2016). The impact of training on pre-service teacher attitudes, concerns, and efficacy towards inclusion. Asia-Pacific Journal of Teacher Education, 44(2), $142-155$

[70] Shields, C. M. (2004). Dialogic leadership for social justice: Overcoming pathologies of silence. Educational Administration Quarterly, 40(1), 109-132.

[71] Sözer, E. (1996). Üniversitelerde öğrenim gören öğretmen adaylarının öğretmenlik mesleğine yönelik tutumları. Anadolu Üniversitesi Eğitim Fakültesi Dergisi, 6(2), 7-21.

[72] Spanierman, L. B., Oh, E., Heppner, P. P., Neville, H. A., Mobley, M., Wright, C. V., Dillon, F. R. \& Navarro, R.
(2010). The multicultural teaching competency scale: Development and initial validation. Urban Education. 46, 440-464. DOI: http://dx.doi.org/10.1177/0042085910377442

[73] Tabachnick, B. G. \& Fidell, L. S. (2007). Using Multivariate Statistics (5th Ed.). New York: Allyn and Bacon.

[74] Tavşancıl, E. (2010). Tutumların Ölçülmesi ve SPSS ile Veri Analizi. Ankara: Nobel Yayın.

[75] Taylor, S. V., \& Sobel, D. M. (2001). Addressing the discontinuity of students' and teachers' diversity: A preliminary study of preservice teachers' beliefs and perceived skills. Teaching and Teacher Education, 17, 487-503.

[76] Teicher, J. M. (1997). Effect of multicultural music experience on preservice elementary teachers' attitudes. Journal of Research in Music Education, 45(3), 415-427.

[77] Tekin, H. (2000). Eğitimde Ölçme ve Değerlendirme, (14. Bask1). Ankara: Yarg1.

[78] Tekinalp, Ș. (2005). Küreselleşen dünyanın bunalımı: Çokkültürlülük. Journal of İstanbul Kültür University, 1, 75-87.

[79] Turkish Language Association ([TLA], Türk Dil Kurumu), (2009). Büyük Türkçe Sözlük. Retrieved 12 February 2014, from: http://tdkterim.gov.tr/bts/

[80] Valentiin, S. (2006). Addressing diversity in teacher education programs. Education, 127(2), 196-202.

[81] Velicer, W. F. \& Fava, J. L. (1998). Effects of variable and subject sampling on factor pattern recovery. Psychological Methods, 3(2), 231-251.

[82] Wallerstein, I. (1990). Culture as the ideological battleground of the modern world-system. Theory, culture and society, 7(2-3), 31-55.

[83] Wigfield, A. \& Eccles, J. S. (2002). The development of competence beliefs, expectancies for success, and achievement values from childhood through adolescence. (Eds: Wigfield A. \& Eccles, J. S). Development of achievement motivation, (pp. 91-120). London: Elsevier, Academic Press

[84] Wiggins, R. A., Follo, E. J. \& Eberly, M. B. (2007). The impact of a field immersion program on pre-service teachers' attitudes toward teaching in culturally diverse classrooms. Teaching and Teacher Education, 23(5), 653-663.

[85] Williams, R. (1977). Culture and Society: 1780-1950. Middlesex: Penguin Books.

[86] Bandura, A. (1997). Self-Efficacy: The Exercise of Control. New York: Freeman.

[87] Pajares, F. (1996). Self-efficacy beliefs in academic settings. Review of Educational Research, 66, 543-578

\footnotetext{
${ }^{\mathrm{i}}$ The study is produced from PhD Dissertation prepared by Soner Yildırım
} 